University of Nebraska - Lincoln

DigitalCommons@University of Nebraska - Lincoln

Agronomy \& Horticulture - Faculty Publications

Agronomy and Horticulture Department

1986

\title{
Growth And Magnesium Uptake Of Tall Fescue Lines At High And Low Potassium Levels
}

\author{
J. H. Edwards \\ Auburn University \\ Jeffrey F. Pedersen \\ University of Nebraska-Lincoln, jpedersen1@unl.edu
}

Follow this and additional works at: https://digitalcommons.unl.edu/agronomyfacpub

Part of the Agricultural Science Commons, Agriculture Commons, Agronomy and Crop Sciences Commons, Botany Commons, Horticulture Commons, Other Plant Sciences Commons, and the Plant Biology Commons

Edwards, J. H. and Pedersen, Jeffrey F., "Growth And Magnesium Uptake Of Tall Fescue Lines At High And Low Potassium Levels" (1986). Agronomy \& Horticulture -- Faculty Publications. 950.

https://digitalcommons.unl.edu/agronomyfacpub/950

This Article is brought to you for free and open access by the Agronomy and Horticulture Department at DigitalCommons@University of Nebraska - Lincoln. It has been accepted for inclusion in Agronomy \& Horticulture -Faculty Publications by an authorized administrator of DigitalCommons@University of Nebraska - Lincoln. 
JOURNAL OF PLANT NUTRITION, 9(12), 1499-1518 (1986)

\author{
GROWTH AND MAGNESIUM UPTAKE OF TALL FESCUE LINES \\ AT HIGH AND LOW POTASSIUM LEVELS 1 \\ J. H. Edwards, and J.F. Pedersen 2 \\ U.S. Department of Agriculture, Agricultural Research \\ Service, Soil-Plant Interation Research Unit, \\ Department of Agronomy and Soils, \\ Alabama Agricultural Experiment Station, \\ Auburn University, AL 36849
}

Key Words: Root diameter, xylem diameter, nutrient concentration, relative growth rate, nutrient solution, mineral nutrition, Festuca arundinacea.

ABSTRACT :

Five tall fescue (Festuca arundinacea Schreb.) clonal lines with diverse root and xylem diameters were grown in nutrient solutions with magnesium ( $\mathrm{Mg}$ ) concentrations of 42,125 and 250 $\mu \underline{M}$ and potassium $K$ concentrations of 133 and $333 \mu \underline{M}$. Leaf $\mathrm{Mg}$ concentrations increased with increasing $\mathrm{Mg}$ rates at both low and high $K$ concentrations. The tall fescue line with the largest root and xylem diameters had low leaf $\mathrm{Mg}$ concentrations, indicating a possible increased Mg tetany potential when consumed by cattle. The response of the $\mathrm{K} /(\mathrm{Mg}+\mathrm{Ca})$ ratio in the plant, an indicator of tetany potential, to varying solution $\mathrm{Mg}$ at $\mathrm{low}$ and

AAES Journal No. 3-861036 
high $\mathrm{K}$ was determined for each of the five lines. No $\mathrm{Mg}$ effects or interactions were significant. Line, $K$, and line $x \mathrm{~K}$ effects were all significant for the $\mathrm{K} /(\mathrm{Mg}+\mathrm{Ca})$ ratios. The line with the largest root and xylem diameters had the highest tetany potential (highest cation ratio). Higher solution $\mathrm{K}$ gave higher $\mathrm{K} /(\mathrm{Mg}+\mathrm{Ca})$ ratios.

\section{INTRODUCTION}

Two important features of breeding tall fescue (Festuca arundinacea Schreb.) for the Coastal Plain region of the Southeastern United States are that: 1) tall fescue must be persistent; and 2) tall fescue should accumulate adequate $\mathrm{Mg}$ to prevent deficiences in forage for consuming ruminants. Accumulation of minerals in forage appears to be under genetic control, 3,4 with relatively high heritability estimates for $\mathrm{Ca}, \mathrm{Mg}$ and the cation ratio $\mathrm{K} /(\mathrm{Ca}+\mathrm{Mg})$ in Loluim-Festuca hybrids ${ }^{5}$. However, with randomly chosen tall fescue clones, low heritability estimates were obtained for $\mathrm{K} /(\mathrm{Ca}+\mathrm{Mg})^{6,7}$. Previous experiments dealt with the foliar portion and no consideration was given to root morphological differences in tall fescue.

Williams et $a 1.8$ demonstrated that morphological differences in roots existed among tall fescue genotypes, and these differences were associated with drought resistance due to differential penetration of plowpans. In their study, a tall fescue clone with large root diameter (LRD) penetrated to soil depths beyond $1 \mathrm{~m}$, while a tall fescue clone with small root diameter (SRD) was limited to the top $25 \mathrm{~cm}$. In greenhouse experiments, SRD had greater water-use efficiency and forage and dry matter production than did LRD when lance (Hoplolaimus spp.) nematodes were present. However, under field conditions, LRD had a higher percentage of survival than SRD because of its ability to penetrate the plowpan, permitting a larger percentage of 
the total root system to grow beneath the nematode-infested soil ${ }^{8}$.

With nutrient solution experiments in the greenhouse, root morphology of tall fescue clones influenced $\mathrm{Mg}$ uptake and growth of selected tall fescue cones ${ }^{9}$. In greenhouse experiments, reduced $\mathrm{Mg}$ concentration in the leaf and roots was associated with elevated $\mathrm{K}$ levels10,11. However, limited information is available regarding the effects of tall fescue root morphology (root and xylem diameter) on $\mathrm{Mg}$ uptake at different $\mathrm{K}$ levels. Considerable research has been directed towards selecting tall fescue lines that will accumulate adequate $\mathrm{Mg}$ to prevent hypomagnesemic tetany in ruminants $4,6,7,12,13$. Magnesium accumulative ability should be maintained or improved when selecting tall fescue clones for root types that will penetrate compacted soils. Thus, the objectives of this study were to determine the effects of: 1) root diameter on the $\mathrm{Mg}$-and $\mathrm{K}$-absorbing ability of tall fescue at various $\mathrm{Mg}$ and $\mathrm{K}$ concentrations; and 2) root and xylem diameter on $\mathrm{K} /(\mathrm{Mg}+\mathrm{Ca})$ ratio in forage.

\section{MATERIALS AND METHODS}

Five clonal lines of tall fescue were used in this study. Two were classified as LRD ( $\mathrm{AU} 7$ and $\mathrm{AU}$ 264) and two as SRD ( $\mathrm{AU} 5$ and $\mathrm{AU}$ 718) in an earlier study (C. B. Williams. 1982. Root system morphology of tall fescue, Festuca arundinacea Schreb.: The evaluation of selected genotypes for cultivar improvement. Ph.D. Thesis, Auburn University, Alabama). A single clone of previously undetermined root diameter, selected at random from 'Kentucky 31' (Ky 31) tall fescue, was included for comparison. The clonal material was preconditioned in nutrient solution to produce propagules with roots free of soil contamination. Uniform single shoot propagules were removed from the 'parent' clones, washed for 2 hours in distilled water, and transferred into individual 12-1iter tanks in the greenhouse. 
Nutrient concentrations were $0.25 \mathrm{mM} \mathrm{NaH}_{2} \mathrm{PO}_{4}, 0.25 \mathrm{mM}$ $\mathrm{NH}_{4} \mathrm{NO}_{3}, 0.5 \mathrm{mM} \mathrm{CaCl}_{2}, 180 \mu \mathrm{M}$ FeDTPA (diethylene triaminepentacetic acid), $46 \mu \underline{M} B, 9 \mu \underline{M n}, 0.8 \mu \underline{M} \mathrm{Zn}, 0.3 \mu \underline{\mathrm{M}} \mathrm{Cu}$, and $0.05 \mu \mathrm{M}$ Mo. When the tall fescue propagules were transferred into the tanks, $\mathrm{Mg}$ concentrations of 42,125 , and $250 \mu \mathrm{M}$, and $\mathrm{K}$ concentration of 133 and $333 \mu$ were imposed on individual tanks by the addition of $\mathrm{MgSO}_{4}$ and $\mathrm{KCl}$. Nutrient concentrations were monitored every two days by removing $50 \mathrm{ml}$ of solution from each tank and determining the nutrient concentrations by standard methods. Nutrient concentrations were maintained by addition of nutrients as required. Nutrient concentrations did not vary more than $5 \%$ from their specified concentration during the course of the experiment.

Solution $\mathrm{pH}$ was measured daily and maintained at 5.6 to 5.8 by adding $\mathrm{HCl}$ or $\mathrm{NaOH}$. To minimize the fluctuation of the solution $\mathrm{pH}$, the sodium salt of 2-(N-Morpholino) ethanesulfonic acid ( $\mathrm{pH}$ 6.15) was added to the nutrient solution to a final concentration of $1 \mathrm{mM}$. All tanks were vigorously aerated, and nutrient solutions were changed every seven days. Temperature was maintained at $24^{\circ} \pm 5^{\circ} \mathrm{C}$, and sunlight was supplemented with fluorescent light to produce a minimum of $250-300 \mathrm{uEm}^{-2} \mathrm{~s}^{-1}$ at the canopy for a 16-hour day.

An experimental unit consisted of two propagules (paired) of each clonal line at each $\mathrm{Mg}$ level. Individual propagules were supported by foam rubber collars in No. 6 plastic stoppers in a 0.5 -cm-thick black plexiglass 16 tank cover. After growing for 41 days, one propagule was harvested. The other propagule was harvested at 83 days. Roots were washed in diluted Ca solution $\left(10^{-4} \underline{M}\right)$ for 15 minutes to remove $a 11 \mathrm{Mg}$ and $\mathrm{K}$ in the free space of root cells. The propagules were separated into shoots (leaf blades, leaf sheaths, and stems) and roots, freeze-dried, weighed, and ground to pass a 40-mesh screen. Root volume was determined at harvest using a water-displacement method prior to 
freeze drying. Concentrations of $\mathrm{Mg}$ and $\mathrm{K}$ in the tissue were determined by Inductively Coupled Argon Plasma. Magnesium and $\mathrm{K}$ uptake rates were calculated from the change in total $\mathrm{Mg}$ and $\mathrm{K}$ contents and the change in fresh weight of tall fescue propagule roots using the following equation:

$$
I_{m}=\frac{M_{2}-M_{1}}{W_{2}-W_{1}} \cdot \ln \frac{\left(W_{2} / W_{1}\right)}{t_{2}-t_{1}}
$$

where $I_{m}$ is influx rate per gram fresh weight of root, $M$ is total elemental content in tall fescue propagule (leaves + roots), WR is fresh root weight, and $t$ is time (days). $I_{m}$ for the first growth period (subscripts 1 and 2 ) denotes initial and first harvest, and for the second growth period denotes initial and second harvest.

The experimental design was a randomized complete block with four replications. Treatments were arranged in a factorial design ( 5 clones $\times 3 \mathrm{Mg}$ concentrations $\mathrm{x} 2 \mathrm{~K}$ concentrations). Data were analyzed using standard analysis of variance and regression analysis.

\section{RESULT AND DISCUSSION}

\section{Growth}

Shoot dry matter (leaf blades, leaf sheaths, and stems) accumulation was not affected by $\mathrm{Mg}$ or $\mathrm{K}$ solution concentration at either the 41- or 83-day growth period (Table 1). Differences in shoot dry matter production due to tall fescue lines were observed at both the 41- and 83-day growth period with the Ky 31 clone having the highest dry matter accumulation. The tall fescue line $\mathrm{AU}-5$ with small root diameter out yielded the large root diameter ( $\mathrm{AU}-7$ and $\mathrm{AU}-264$ ) lines for both growth periods. However, the dry matter production of the SRD AU-718 1 ine was 
TABLE 1

Means of shoot dry matter accumulation of five tall fescue lines at high and low solution $\mathrm{K}$ concentration.

\begin{tabular}{|c|c|c|c|c|c|c|c|}
\hline \multirow{3}{*}{\multicolumn{2}{|c|}{$\begin{array}{l}\text { Fescue } \\
\text { lines }\end{array}$}} & \multicolumn{2}{|c|}{ Harvest 1} & \multirow{3}{*}{$\begin{array}{l}\text { Line } \\
\text { mean }\end{array}$} & \multicolumn{2}{|c|}{ Harvest 2} & \multirow{3}{*}{$\begin{array}{l}\text { Line } \\
\text { mean }\end{array}$} \\
\hline & & \multicolumn{2}{|c|}{$\mathrm{K}$ concentration } & & \multicolumn{2}{|c|}{$\overline{\mathrm{K} \text { concentration }}$} & \\
\hline & & 133 & 333 & & 133 & 333 & \\
\hline $\mathrm{AU}-7$ & (LRD) & 1.15 & 1.43 & 1.29 & 2.53 & 2.55 & 2.54 \\
\hline$A U-264$ & (LRD) & 1.43 & 1.37 & 1.40 & 4.54 & 4.23 & 4.39 \\
\hline $\mathrm{AU}-5$ & (SRD) & 1.72 & 1.87 & 1.80 & 5.74 & 5.01 & 5.38 \\
\hline $\mathrm{AU}-718$ & (SRD) & 1.42 & 1.57 & 1.49 & 3.67 & 3.94 & 3.81 \\
\hline Ky 31 & & 1.96 & 2.26 & 2.10 & 7.95 & 6.27 & 7.11 \\
\hline $\begin{array}{c}\mathrm{K} \\
\text { mean }\end{array}$ & & 1.54 & 1.70 & & 4.89 & 4.40 & \\
\hline $\mathrm{FLSD}_{05}$ & $\mathrm{~K}$ & & & & ns & & \\
\hline $\mathrm{FLSD}_{05}$ & $\mathrm{~L}$ & 0.31 & & & 0.87 & & \\
\hline
\end{tabular}

TABLE 2

Means of root volume of five tall fescue lines at high and low solution $\mathrm{K}$ concentration.

\begin{tabular}{|c|c|c|c|c|c|c|c|}
\hline \multirow{3}{*}{$\begin{array}{l}\text { Fescue } \\
\text { lines } \\
\end{array}$} & & \multicolumn{2}{|c|}{ Harvest 1} & \multirow{3}{*}{$\begin{array}{l}\text { Line } \\
\text { mean }\end{array}$} & \multicolumn{2}{|c|}{ Harvest 2} & \multirow{3}{*}{$\begin{array}{l}\text { Line } \\
\text { mean }\end{array}$} \\
\hline & & \multicolumn{2}{|c|}{$\mathrm{K}$ concentration } & & \multicolumn{2}{|c|}{$\mathrm{K}$ concentration } & \\
\hline & & 133 & 333 & & 133 & 333 & \\
\hline $\mathrm{AU}-7$ & （LRD） & 7.6 & 10.3 & 9.0 & 18.1 & 16.2 & 17.2 \\
\hline$A U-264$ & （LRD） & 9.0 & 9.3 & 9.2 & 51.0 & 37.4 & 44.2 \\
\hline $\mathrm{AU}-5$ & （SRD） & 14.2 & 16.0 & 15.2 & 66.7 & 54.2 & 60.5 \\
\hline $\mathrm{AU}-718$ & （SRD） & 15.3 & 13.6 & 14.5 & 29.3 & 32.3 & 30.8 \\
\hline Ky 31 & & 17.3 & 17.1 & 17.2 & 47.2 & 41.3 & 44.6 \\
\hline $\begin{array}{c}\mathrm{K} \\
\text { mean }\end{array}$ & & 12.7 & 13.3 & & 42.6 & 36.3 & \\
\hline $\mathrm{FLSD}_{05}$ & $\mathrm{~K}$ & ns & & & ns & & \\
\hline FLSD $_{05}$ & L & 2.31 & & & 10.64 & & \\
\hline
\end{tabular}


similar to the two LRD lines. There was no significant interaction at either growth period.

Root volume was not affected by $\mathrm{Mg}$ or $\mathrm{K}$ solution concentration at either the 41- or 83-day growth period and none of the interactions were significant. The root volume of the SRD and the single selection of $\mathrm{Ky} 31$ fescue clone were appproximately two-fold larger than the LRD lines (Table 2) for the first growth period (41 days). The root volume of the $\mathrm{AU}-5$ line was two times the root volume of the LRD for the 83-day growth period. The AU-7 line consistently had the smallest root volume at both growth periods. One of the possible reasons for the larger root volume of the SRD ( $\mathrm{AU}-5$ and $\mathrm{AU}-718$ ) fescue lines was a result of them having a greater number of secondary roots/cm of primary root than the LRD ( $A U-7$ and $A U-264$ ) fescue 1 ines.

\section{Tissue nutrient concentration}

Shoot $K$ concentration was influenced by $K$ levels and tall fescue 1 ines for both the 41 - and 83-day growth periods (Table 3 ). At the 41-day growth period, $\mathrm{AU}-5$ (SRD) and $\mathrm{AU}-7$ (LRD) tall fescue lines had 2.87 and $2.77 \% R$ at the $133 \mu \mathrm{M} K$ level and $3.5 \%$ $K$ at the the $333 \mu \mathrm{K}$ level. The other lines ranged from 2.51 to $2.62 \% \mathrm{~K}$ at the $133 \mu \underline{M}$ and 3.0 to $3.2 \% \mathrm{~K}$ at the $333 \mu \underline{M}$ level. After the 83-day growth period, shoot $K$ concentration was reduced more than $50 \%$ at the low $\mathrm{K}$ level in all lines and by $4 \%$ at the high $\mathrm{K}$ level. However, $\mathrm{AU}-5$ and $\mathrm{AU}-7$ lines still contained an equal or higher $\mathrm{K}$ concentration at both $\mathrm{K}$ levels when compared to other lines.

Leaf $\mathrm{Mg}$ concentration was influenced by solution $\mathrm{Mg}$ and $\mathrm{K}$, tall fescue 1 ines and interactions of $\mathrm{Mg} \times \mathrm{lines}$ and $\mathrm{K} \times \mathrm{lines.}$ Regression analysis was determined for each line at each $K$ level (Table 4 and Fig. 1). Predicted leaf $\mathrm{Mg}$ concentration was generally linearly related to the $\mathrm{Mg}$ solution concentration for the 41-day growth period. The one exception was the $\mathrm{AU}-7$ at the high $K$ level which followed a quadratic equation for predicting 
TABLE 3

Means of shoot $K$ concentration of five tall fescue 1 ines at high and low solution $R$ concentration.

\begin{tabular}{|c|c|c|c|c|c|c|c|}
\hline \multirow[b]{2}{*}{$\begin{array}{l}\text { Fescue } \\
\text { lines } \\
\end{array}$} & & \multicolumn{2}{|c|}{ Harvest 1} & \multirow[b]{2}{*}{$\begin{array}{l}\text { Line } \\
\text { mean }\end{array}$} & \multicolumn{2}{|c|}{ Harvest 2} & \multirow[b]{2}{*}{$\begin{array}{l}\text { Line } \\
\text { mean }\end{array}$} \\
\hline & & $\begin{array}{l}\mathrm{Kcor} \\
133 \\
\end{array}$ & $\begin{array}{c}\text { entration } \\
333 \\
\end{array}$ & & $\begin{array}{l}\mathbf{R} \text { con } \\
133 \\
\end{array}$ & $\begin{array}{c}\text { atration } \\
333 \\
\end{array}$ & \\
\hline $\begin{array}{l}\mathrm{AU}-7 \\
\mathrm{AU}-264 \\
\mathrm{AU}-5 \\
\mathrm{AU}-718 \\
\mathrm{Ky} 31\end{array}$ & $\begin{array}{l}\text { (LRD) } \\
\text { (LRD) } \\
\text { (SRD) } \\
\text { (SRD) }\end{array}$ & $\begin{array}{l}27.71 \\
26.25 \\
28.71 \\
26.00 \\
25.19\end{array}$ & $\begin{array}{l}35.13 \\
30.34 \\
34.99 \\
30.88 \\
32.60\end{array}$ & $\begin{array}{l}31.42 \\
28.90 \\
31.85 \\
28.45 \\
28.89\end{array}$ & $\begin{array}{l}13.16 \\
12.98 \\
13.94 \\
13.15 \\
11.23\end{array}$ & $\begin{array}{l}20.24 \\
19.20 \\
20.84 \\
18.71 \\
18.66\end{array}$ & $\begin{array}{l}16.70 \\
16.09 \\
17.39 \\
20.84 \\
14.94\end{array}$ \\
\hline$\stackrel{\mathrm{K}}{\text { Mean }}$ & & 26.78 & 32.74 & & 12.89 & 19.53 & \\
\hline $\begin{array}{l}\text { FLSD05 } \\
\text { FLSD05 }\end{array}$ & $\begin{array}{l}\text { K } \\
\text { L }\end{array}$ & $\begin{array}{l}1.38 \\
2.18\end{array}$ & & & $\begin{array}{l}0.60 \\
0.95\end{array}$ & & \\
\hline
\end{tabular}

leaf Mg concentration. At the low $\mathrm{K}$ level, the leaf Mg concentration of the LRD ( $\mathrm{AU}-7$ and $\mathrm{AU}-264$ ) was lower when compared to the SRD ( $\mathrm{AU}-5$ and $\mathrm{AU}-718$ ) and $\mathrm{Ky} 31$.

The $\mathrm{Mg} \times$ line interaction occurred with the AU-264 line at the low $\mathrm{K}$ level. When increasing the Mg concentration from 125 $\mu \underline{M}$ to $250 \mu \underline{M}$, little increase in leaf $M g$ concentration was observed in the $\mathrm{AU}-264$ lines when compared to the other lines. The $\mathrm{K} \times$ line interaction occurred with the $\mathrm{AU}-5$ line at the 333 쓰 $\mathrm{K}$ level. A rapid increase in leaf $\mathrm{Mg}$ was observed when the $\mathrm{Mg}$ concentration was increased from $125 \mu \underline{M}$ to $250 \mu \underline{M}$. A reduced leaf $\mathrm{Mg}$ concentration was associated with high solution $\mathrm{K}$ concentration in the 41-day growth period, indicating higher $\mathrm{Mg}$ tetany potenial under high $\mathrm{K}$ fertilization.

At the 83-day growth period, solution $\mathrm{Mg}$ and $\mathrm{K}$ concentration and lines gave significant differences in leaf $\mathrm{Mg}$ concentration (Table 5 and Fig. 2). Predicted leaf Mg concentration was generally linearly related to the $\mathrm{Mg}$ solution con- 
TABLE 4

Leaf regression equation for prediction of $\mathrm{Mg}$ concentration after 41 days of growth in nutrient solution containing selected $\mathrm{Mg}$ and $\mathrm{K}$ concentration.

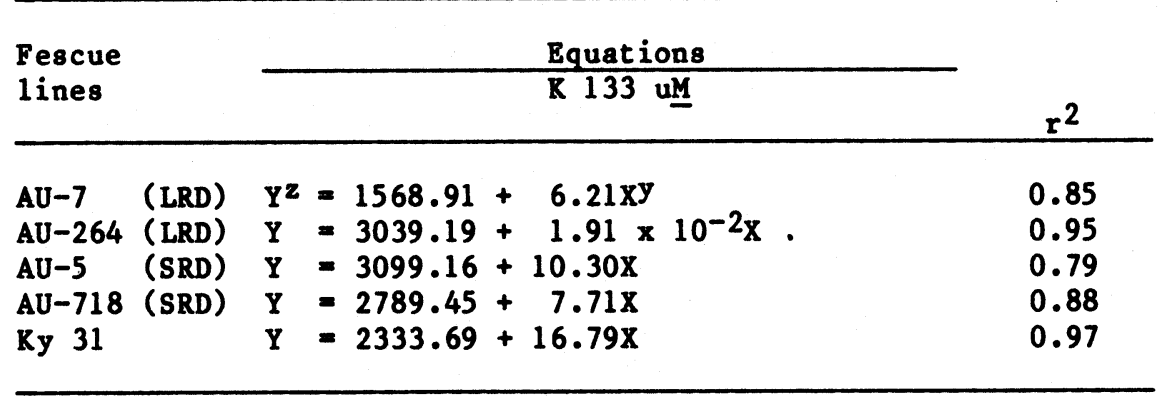

\section{K 333 uM}

\begin{tabular}{llll}
\hline $\mathrm{AU}-7$ & (LRD) & $\mathrm{Y}=1465.68+1.91 X$ & 0.83 \\
$\mathrm{AU}-264$ (LRD) & $\mathrm{Y}=2398.08+2.78 \mathrm{X}$ & 0.88 \\
$\mathrm{AU}-5$ & (SRD) & $\mathrm{Y}=2808.49+1.91 X$ & 0.90 \\
$\mathrm{AU}-718(\mathrm{SRD})$ & $\mathrm{Y}=2400.44+10.52 \mathrm{X}$ & 0.95 \\
$\mathrm{Ky} 31$ & $\mathrm{Y}=2644.15+5.52 \mathrm{X}$ & 0.87
\end{tabular}

ZY = predicted $\mathrm{Mg}_{\mathrm{g}}$ concentration.

$y_{X}=\mathrm{Mg}$ concentration in leaf tissue.

centration. The two exceptions were $\mathrm{AU}-264$ at the low $\mathrm{K}$ level and $\mathrm{AU}-7$ at the high $\mathrm{K}$ level. In these instances, the LRD lines followed a quadratic equation for predicting leaf $\mathrm{Mg}$ concentration at both $\mathrm{K}$ levels. The $\mathrm{AU}-718$ line was not influenced by $\mathrm{Mg}$ concentration. In the 83-day growth period, the leaf $\mathrm{Mg}$ concentration of LRD ( $\mathrm{AU}-7$ and $\mathrm{AU}-264$ ) was lower when compared to the other lines. Also, the line $\mathrm{AU}-7$ showed tissue $\mathrm{Mg}$ concentration at the 83-day growth period below the $1.9 \mathrm{~g} / \mathrm{kg}$ level suggested by Kemp and $t^{\prime H a r t}{ }^{14}$ as critical for causing $\mathrm{Mg}$ tetany.

\section{Nutrient influx rate}

The influx rate of $K$ was influenced by $K$ levels and tall fescue lines at both growth periods (Table 6). At the 41-day 


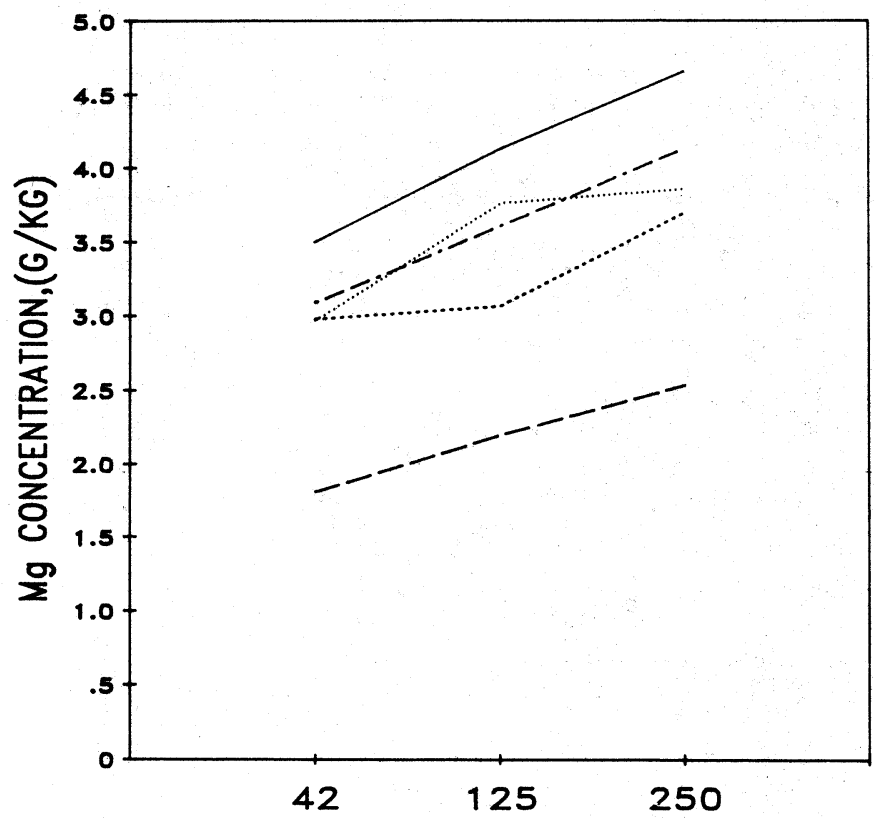

$$
\begin{aligned}
& \text { LEGEND } \\
& -A U 5 \\
& \ldots A U 7 \\
& \ldots . . . A U 264 \\
& \ldots \text { AU } 718 \\
& \text { K.... KY } 31
\end{aligned}
$$

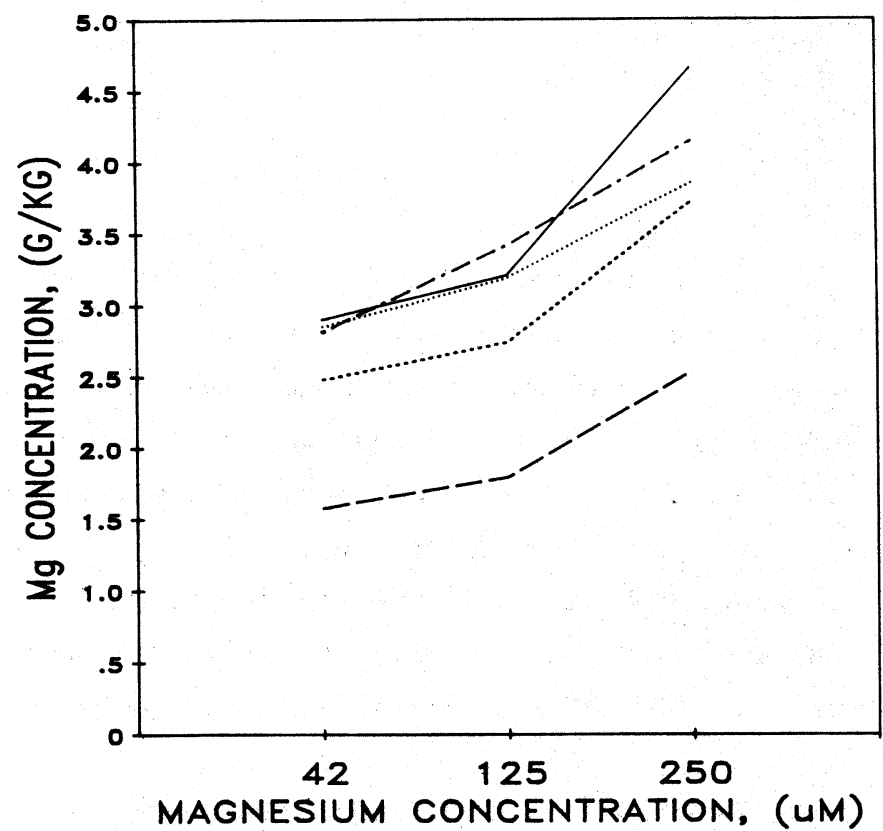

LEGEND

$A \cup 5$

AU 7

AU 264

$A \cup 718$

KY 31

Figure 1. Leaf $\mathrm{Mg}$ concentration in five fescue lines after 41 days of growth in nutrient solution containing selected $\mathrm{Mg}$ and $\mathrm{K}$ concentration. 


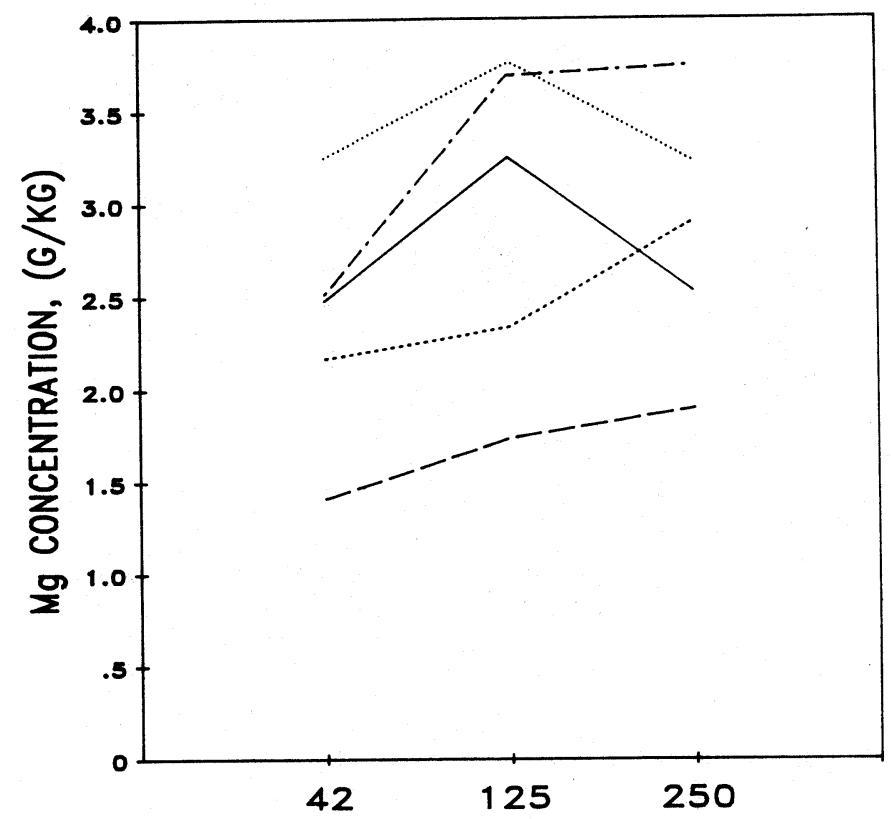

LEGEND

$A \cup 5$

$A \cup 7$

AU 264

AU 718

KY 31

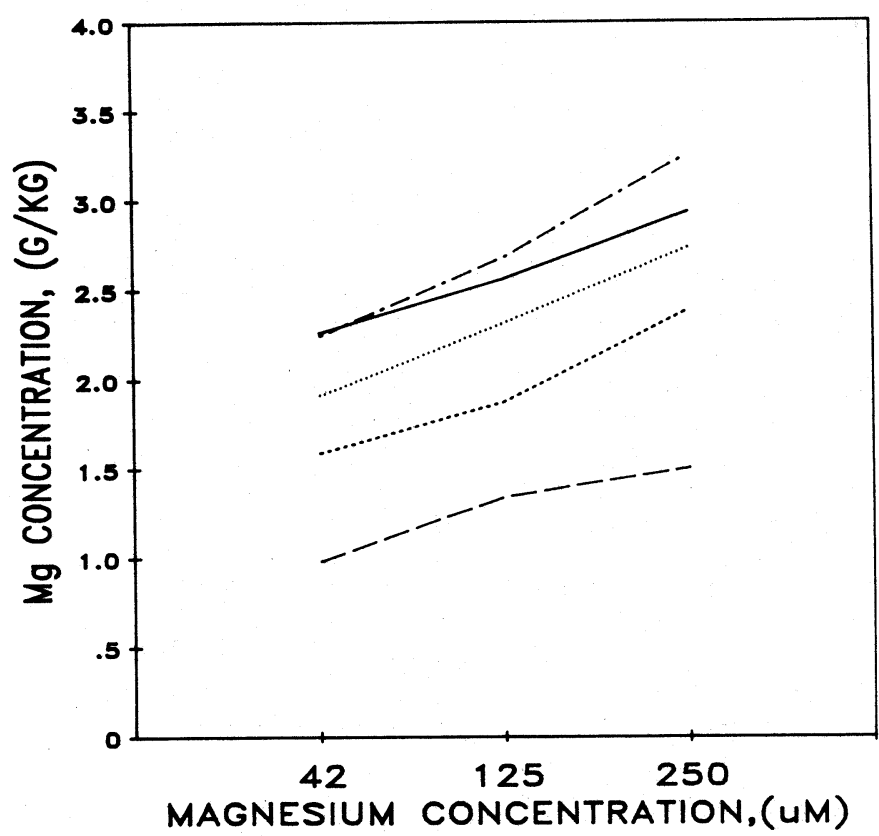

LEGEND

AU 5

$A \cup 7$

AU 264

AU 718 KY 31

Figure 2. Leaf $\mathrm{Mg}$ concentration in five fescue lines after 83 days of growth in nutrient solution containing selected $\mathrm{Mg}$ and $\mathrm{K}$ concentration. 
TABLE 5

Leaf regression equation for prediction of $\mathrm{Mg}$ concentration after 83 days of growth in nutrient solution containing selected $\mathrm{Mg}$ and $\mathrm{K}$ concentration.

Fescue

Equations

lines

$\mathbf{r}^{2}$

$\begin{array}{llll}\mathrm{AU}-7 & \text { (LRD) } & \mathrm{Y}^{\mathrm{Z}}=1184.12+6.08 \times \mathrm{Y} & 0.77 \\ \mathrm{AU}-264 \text { (LRD) } & \mathrm{Y}=2156.82+3.22 \times 10^{-2} \mathrm{X} & 0.86 \\ \mathrm{AU}-5 & \text { (SRD) } & \mathrm{Y}=1968.12+13.45 \mathrm{X} & 0.92 \\ \mathrm{AU}-718(\mathrm{SRD}) & \mathrm{Y}=1560.47+25.41 \mathrm{X} & 0.71(\mathrm{~ns}) \\ \mathrm{Ky} 31 & \mathrm{Y}=1681.50+5.11 \mathrm{X} & 0.89\end{array}$

K 333 uM

\begin{tabular}{llll}
\hline $\mathrm{AU}-7$ & (LRD) & $\mathrm{Y}=724.24+6.88 \mathrm{X}-1.51 \times 10^{-2} \mathrm{X}^{2}$ & 0.96 \\
$\mathrm{AU}-264$ (LRD) & $\mathrm{Y}=1482.77+2.61 \mathrm{X}$ & 0.77 \\
$\mathrm{AU}-5$ & (SRD) $\mathrm{Y}=2103.74+4.03 \mathrm{X}$ & 0.95 \\
$\mathrm{AU}-718$ (SRD) $\mathrm{Y}=2007.22+5.93 \mathrm{X}$ & 0.84 \\
$\mathrm{Ky} 31$ & $\mathrm{Y}=1667.94+6.19 \mathrm{X}$ & 0.90
\end{tabular}

ZY $=$ predicted $M g$ concentration.

$\mathrm{YX}=\mathrm{Mg}$ concentration in leaf $\mathrm{tissue}$.

TABLE 6

Means of $\mathrm{K}$ influx rate of five tall fescue lines at high and low solution $\mathrm{K}$ concentration.

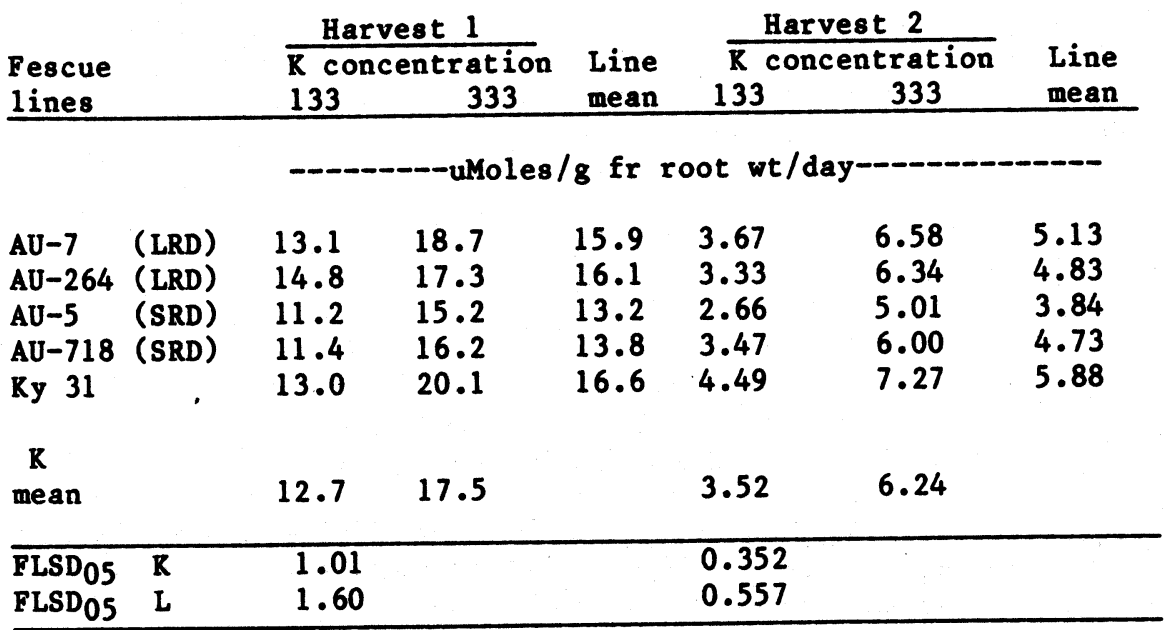


TABLE 7

Magnesium influx regression equation for prediction of $\mathrm{Mg}$ uptake rates after 41 days of growth in nutrient solution containing selected $\mathrm{Mg}$ and $\mathrm{K}$ concentration.

Fescue

lines
Equations

K 133 uM

$\begin{array}{llll}\mathrm{AU}-7 & \text { (LRD) } & \mathrm{Y}^{\mathrm{Z}}=1.48-3.10 \times 10^{-3} \mathrm{X} & 0.81 \\ \mathrm{AU}-264 \text { (LRD) } & \mathrm{Y}=2.15+9.59 \times 10^{-3} \mathrm{X} & 0.40(\mathrm{~ns}) \\ \mathrm{AU}-5 & \text { (SRD) } & \mathrm{Y}=2.09+1.13 \times 10^{-3} \mathrm{X} & 0.49(\mathrm{~ns}) \\ \mathrm{AU}-718(\mathrm{SRD}) & \mathrm{Y}=1.27+7.84 \times 10^{-3} \mathrm{X} & 0.73 \\ \mathrm{Ky} 31 & \mathrm{Y}=1.85+4.44 \times 10^{-3} \mathrm{X} & 0.74\end{array}$

\section{R 333 UM}

$\begin{array}{lllll}\mathrm{AU}-7 & \text { (LRD) } & \mathrm{Y}=0.69+9.22 \times 10^{-2} \mathrm{X}-2.13 \times 10^{-5} \mathrm{X}^{2} & 0.90 \\ \mathrm{AU}-264 \text { (LRD) } \mathrm{Y}=1.92-1.96 \times 10^{-3} \mathrm{X} & 0.81 \\ \mathrm{AU}-5 & \text { (SRD) } \mathrm{Y}=1.17+6.65 \times 10^{-3} \mathrm{X} & 0.91 \\ \mathrm{AU}-718 \text { (SRD) } \mathrm{Y}=1.30+9.32 \times 10^{-3} \mathrm{X} & 0.79 \\ \mathrm{Ky} 31 & \mathrm{Y}=1.12+1.94 \times 10^{-2} \mathrm{X} & 0.84\end{array}$

$\overline{Z_{Y}}=$ predicted $\mathrm{Mg}$ influx rate.

$y_{X}=$ actual $\mathrm{Mg}$ influx rate.

growth period, the $R$ influx rate ranged from 11 to $15 \mathrm{uMoles} / \mathrm{g}$ fr root wt/day at the low $K$ level and from 15 to $20 \mathrm{uMoles} / \mathrm{g} \mathrm{fr}$ root wt/day at the $333 \mu \mathrm{M} K$ level. However, for the 83-day growth period, $K$ influx rate was three-fold lower at both $K$ levels in all 1ines. A possible reason for the decrease in shoot $K$ concentration with physiological age is that tall fescue roots are not $a b l e$ to absorb $K$ at a rate sufficient to meet their needs; or the $K$ that occurs in the old shoots (leaf blades, leaf sheaths, and stems) is being mobilized to actively growing apical areas. As a result, the shoot demands are reduced and subsequently the influx rate of $R$ is reduced.

At the 41-day growth period, the influx of $\mathrm{Mg}$ was increased linearly by $\mathrm{Mg}$ solution concentration in all tall fescue lines 
TABLE 8

Magnesium influx regression equation for prediction of $\mathrm{Mg}$ uptake rates after 83 days of growth in nutrient solution containing selected $\mathrm{Mg}$ and $\mathrm{K}$ concentration.

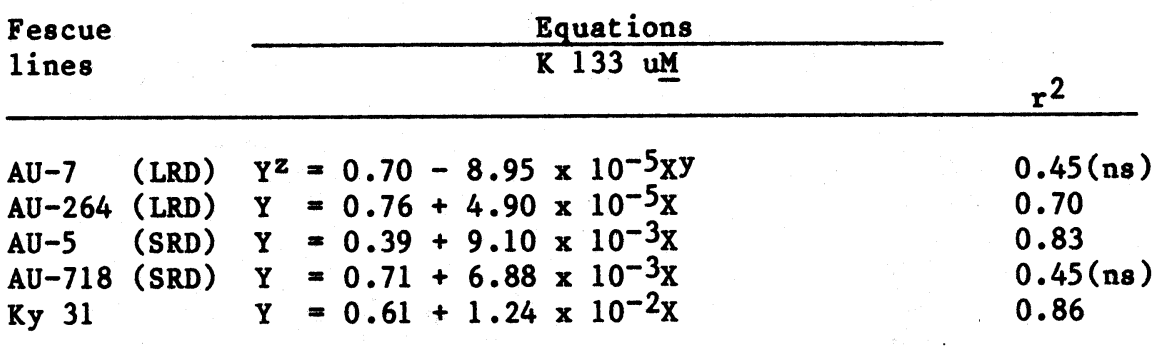

K 333 u

$\begin{array}{lllll}\mathrm{AU}-7 & \text { (LRD) } & \mathrm{Y}=0.33+2.47 \times 10^{-3} \mathrm{X} & 0.95 \\ \mathrm{AU}-264 \text { (LRD) } & \mathrm{Y}=0.98-6.64 \times 10^{-3} \mathrm{X} & 0.68 \text { (ns) } \\ \mathrm{AU}-5 & \text { (SRD) } & \mathrm{Y}=0.49+1.49 \times 10^{-3} \mathrm{X} & 0.90 \\ \mathrm{AU}-718 \text { (SRD) } & \mathrm{Y}=0.66+4.04 \times 10^{-3} \mathrm{X} & 0.73 \\ \mathrm{Ky} 31 & \mathrm{Y}=0.51+1.04 \times 10^{-2} \mathrm{X} & 0.75 \text { (ns) }\end{array}$

ZY $=$ predicted Mg influx rate.

$Y_{X}=$ actual $\mathrm{Mg}$ influx rate.

that responded to solution Mg concentration (Table 7 and Fig. 3). The only exception was the $\mathrm{AU}-7$ line which followed a quadratic equation for predicting $\mathrm{Mg}$ influx rate. The two lines that did not respond to solution $\mathrm{Mg}$ concentration were the AU-264 (LRD) and $\mathrm{AU}-5$ (SRD) at the $133 \mathrm{UM} \mathrm{K}$ level.

At the 83-day growth period, lines that responded to solution $\mathrm{Mg}$ concentration responded linearly (Table 8 and Fig. 4). The lines $\mathrm{AU}-7$ (LRD) and $\mathrm{AU}-718$ (SRD) at the low $\mathrm{K}$ level did not respond to $\mathrm{Mg}$ concentration. The only significant interaction was $\mathrm{Mg} \times$ line. The $\mathrm{AU}-264$ had a higher $\mathrm{Mg}$ influx rate when the Mg concentration was increased from $125 \mu \underline{M}$ to $250 \mu \mathrm{M}$ as compared to the other lines. Relative differences in $\mathrm{Mg}$ influx were reflected in the $\mathrm{Mg}$ tissue differences. This is important since 


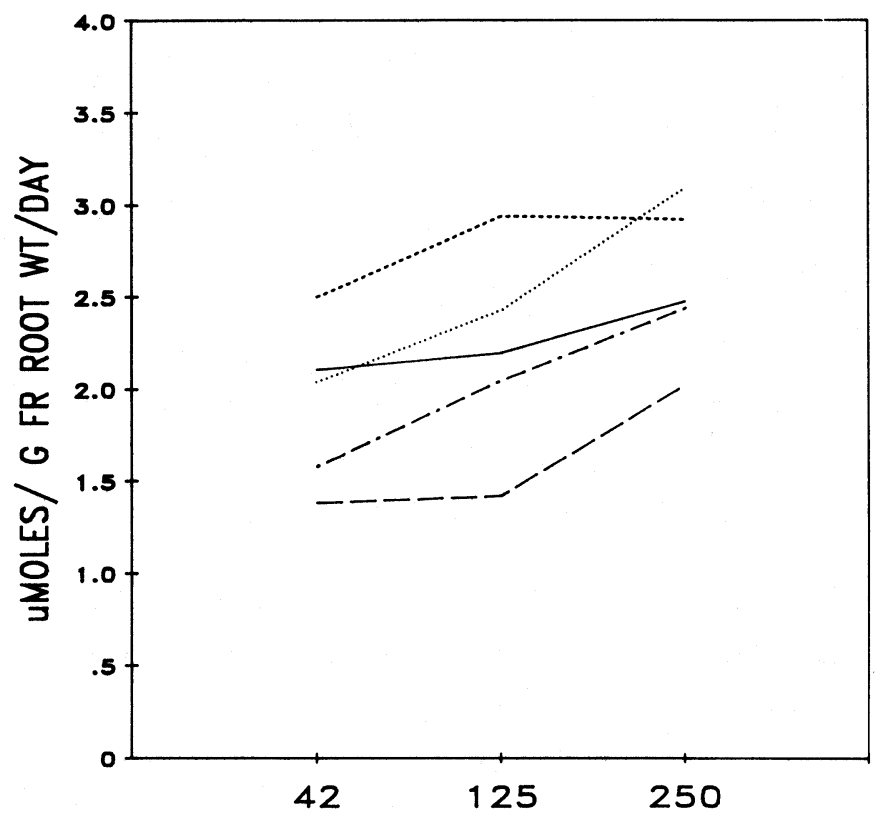

LEGEND

- AU 5

$A \cup 7$

AU 264

AU 718

KY 31

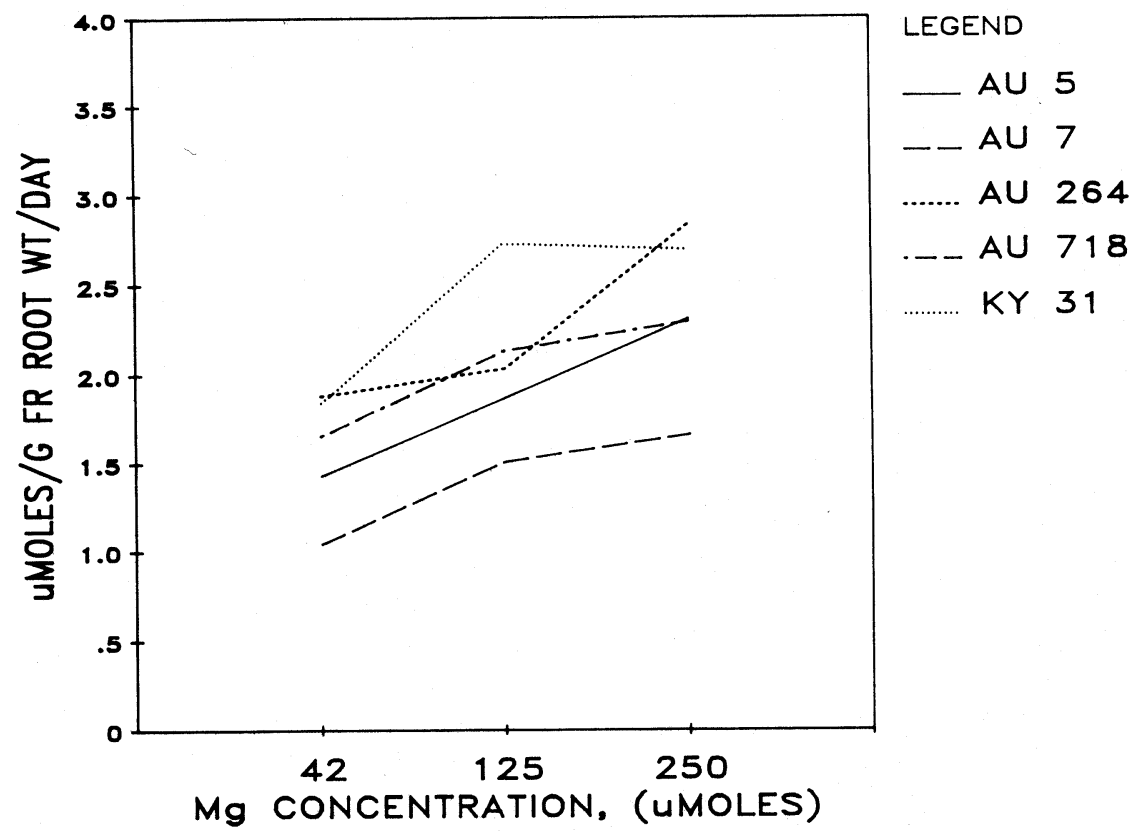

Figure 3. Magnesium influx rate in five fescue lines after 41 days of growth in nutrient solution containing selected $\mathrm{Mg}$ and $\mathrm{K}$ concentration. 


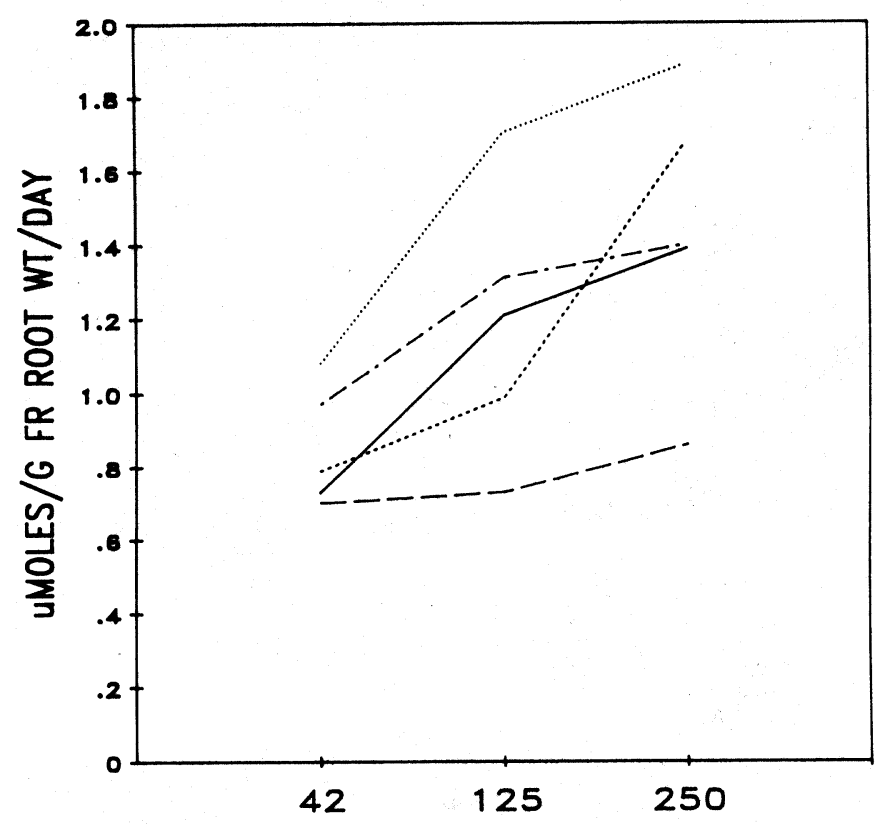

$$
\begin{aligned}
& \text { LEGEND } \\
& \text {-AU } 5 \\
& - \text { AU } 7 \\
& \ldots . . A U 264 \\
& \ldots \text { AU } 718 \\
& \text { KY } 31
\end{aligned}
$$

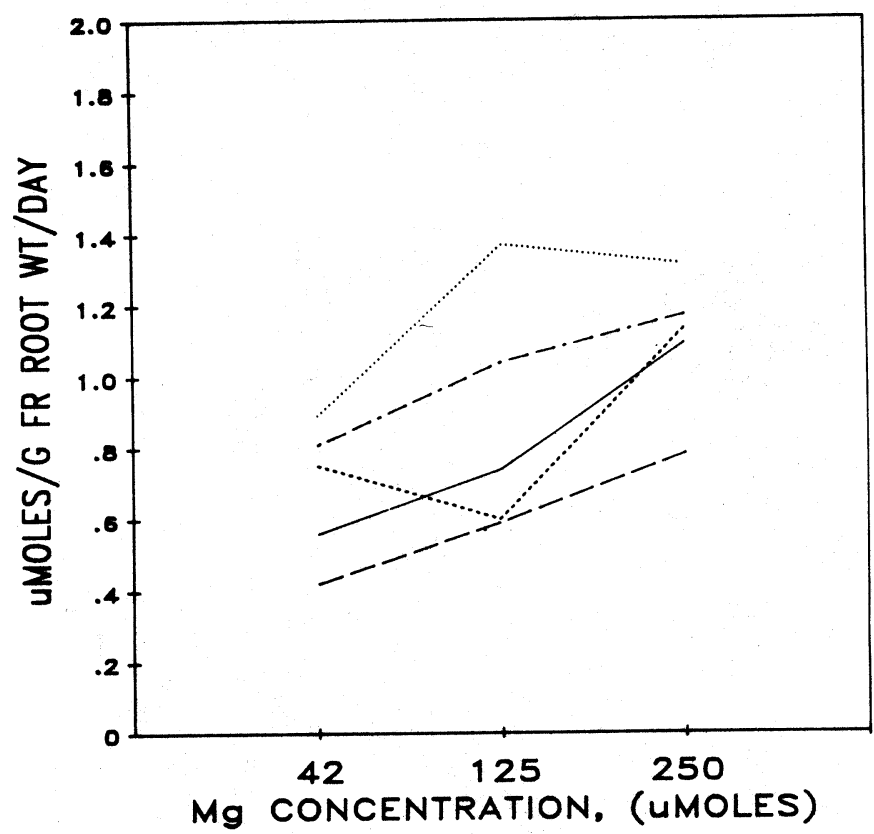

LEGEND

$A \cup 5$

AU 7

AU 264

$A \cup 718$

KY 31

Figure 4. Magnesium influx rate in five fescue lines after 83 days of growth in nutrient solution containing selected $\mathrm{Mg}$ and $\mathrm{K}$ concentration. 


\section{TABLE 9}

Means of $\mathrm{K} /(\mathrm{Ca}+\mathrm{Mg})$ ratios of five tall fescue lines at high and low solution $\mathrm{K}$ concentration.

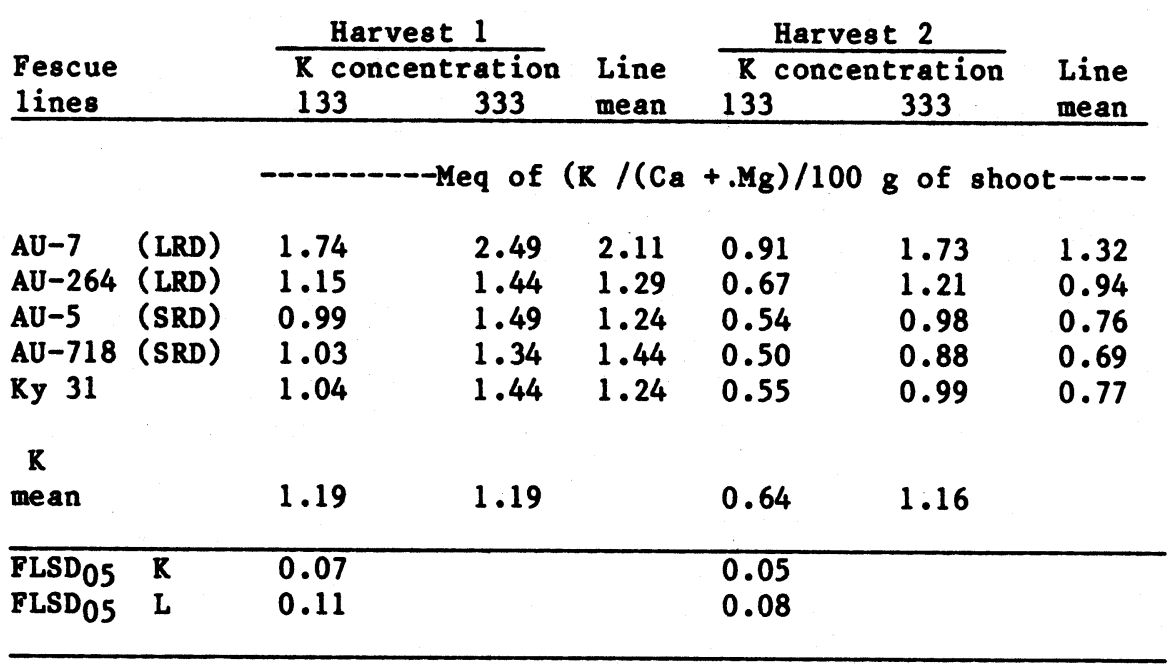

screening for higher $\mathrm{Mg}$ influx appears possible by measuring tissue $\mathrm{Mg}$ concentration in fescue lines.

\section{$\mathrm{R} /(\mathrm{Mg}+\mathrm{Ca})$ ratio}

The $\mathrm{K} /(\mathrm{Mg}+\mathrm{Ca})$ ratio of the five lines was shown to vary with solution $\mathrm{Mg}$ concentration, solution $\mathrm{K}$ concentration, and lines at the 41-day growth period, and with only solution $K$ and lines at the 83-day growth period (Table 9). The solution $K \mathrm{X}$ line interaction was significant in both growth periods. Butler 15 concluded that a ratio of 1 ess than $2.2 \mathrm{meq} / 100 \mathrm{~g}$ of dry matter reduced Mg tetany. No values greater than 2.2 were shown for this ratio in the 83-day growth period, agreeing with the commonly held concept that $M g$ tetany potential is usually highest during early growth. As would be expected, high solution $\mathrm{K}$ concentration consistently resulted in higher $\mathrm{K} /(\mathrm{Mg}+\mathrm{Ca})$ ratios, indicating that high $R$ fertility could contribute to $M g$ tetany 
potential, even though the magnitude of this response varied with lines. Solution $R$ concentration and line effects were more important than solution $\mathrm{Mg}$ concentration in determining this ratio in the 83-day growth period, as shown by the lack of a solution $\mathrm{Mg}$ concentration effect on this trait (data not shown).

\section{SUMMARY}

Root morphology does influence tall fescue lines' ability to absorb Mg. The LRD lines contained less tissue Mg than the SRD or the clonal selection of $\mathrm{Ky} 31$, and this effect is amplified as the plant ages. The concentration of $R$ is also very important in determining the leaf tissue concentration of $\mathrm{Mg}$. We can conclude from this work that, although harvest age and fertility are important in determining the Mg tetany potential of tall fescue, line effects are also important. Furthermore, it appears that the selection of tall fescue lines with LRD may at times increase the risk of $\mathrm{Mg}$ tetany in this species. Breeders selecting for altered root morphology in this, and possibly other species, should therefore continue to monitor the Mg potential of their lines via tissue analyses.

\section{RE FERENCES}

1. Cooperative research between USDA, ARS, Soil-Plant Interaction Research Unit and Alabama Agricultural Experiment Station, Auburn University, AL 36849.

2. Soil Scientist, USDA-ARS-Soil-Plant Interaction Research Unit, Assistant Professor, Agronomy and Soils Department, Auburn University.

3. Hill, R. R. and S. B. Guss. 1976. Genetic variability for mineral concentrations in plants related to mineral requirements of cattle. Crop Sci. 16:680-685.

4. Sleper, D. A. 1979. Plant breeding, selection, and species in relation to grass tetany. p.63-77 In V. V. Rendig and D.L. Grunes (eds.) Grass tetany. Am. Soc. Agron., Madison, WI. 
5. Buckner, R. C., P. B. Burris II, P. L. Cornelius, and L. P. Bush. 1981. Genetic variability and heritability of certain forage quality and mineral constituents in Lolium-Festuca hybrid derivatives. Crop Sci. $21: 419-423$.

6. Nyguyen, H. T., and D. A. Sleper. 1981. Genetic variability of mineral concentration in Festuca arundinacea Schreb. Theor. and Appl. Gen. 59:57-63.

7. Sleper, D. A., G. B. Garner, R. H. Asay, R. Boland, and E. E. Pickett. 1977. Breeding for $\mathrm{Mg}, \mathrm{Ca}, \mathrm{K}$, and $\mathrm{P}$ content in tall fescue. Crop Sci. 17:433-438.

8. Williams, C. B., C. B. Elkins, R. L. Haaland, C. S. Hoveland, and R. Rodriguez-Kabana. 1983. Effect of root diameter, nematodes, and soil compaction on two tall fescue genotypes. Proc. XIV Inter. Grasslands Congr., Lexington; KY, June 15-24, 1981.

9. Torbert, H. A., J. H. Edwards, J. F. Pedersen. 1985. Growth and magnesium uptake of tall fescue clones with varying root diameters. J. Plant Nutrition 8(8): 731-749.

10. Hannaway, D. B., L. P. Bush and J. E. Leggett. 1982. Mineral composition of Kenhy tall fescue as affected by nutrient solution concentration of $\mathrm{Mg}$ and $\mathrm{K}$. J. Plant Nutrition 5(3):137-151.

11. Hannaway, D. B., J. E. Leggett, L. P. Bush and P. E. Shuler. 1984. Magnesium (mg) and Rubidium (RB) absorption by tall fescue. J. Plant Nutrition $7(7): 1127-1147$.

12. Sleper, D. A., G. B. Garner, C. J. Nelson, and J. L. Sebaugh. 1980. Mineral concentration of tall fescue genotypes grown under controlled conditions. Agron. J. $72: 720-722$.

13. Haaland, R. L., C. B. Elkins, and C. S. Hoveland. 1978. A method for detecting genetic variability for grass tetany potential in tall fescue. Crop Sci. 18:339-340.

14. Kemp, A. and M. L. t'Hart. 1957. Grass tetany in grazing milking cows. Neth. J. Agric. Sci. 5:4-17.

15. Butler, E. J. 1963. The mineral element content of spring pasture in relation to the occurrence of grass tetany and hypomagnesaemia in dairy cows. J. Agric. Sci. 60:329-340. 
16. Hentlion of e tredenert or proprietery product does not

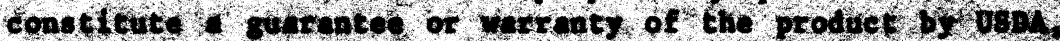

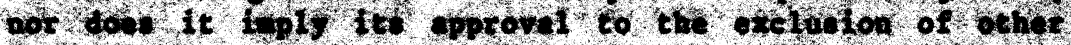
proticter.
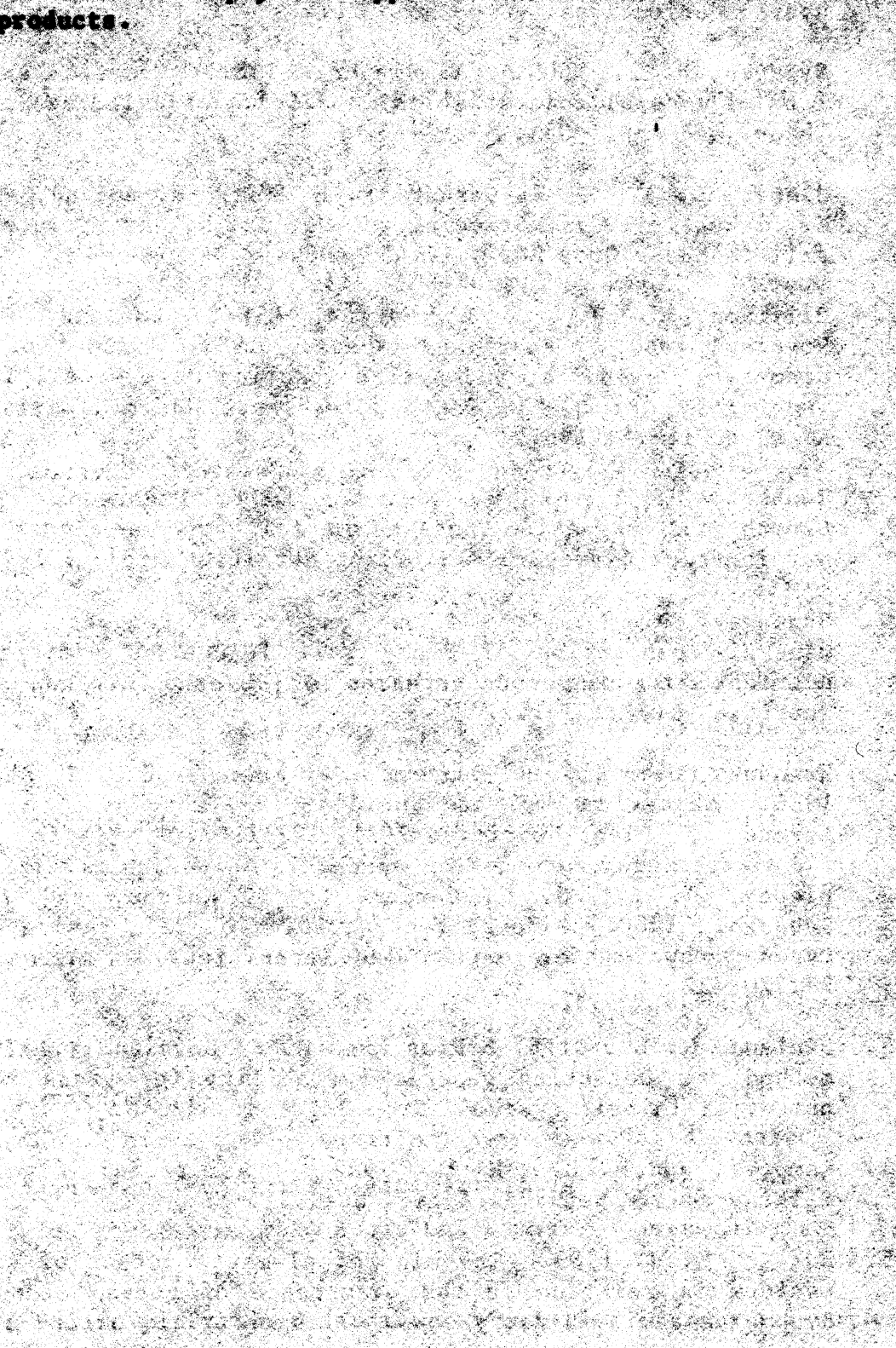